\title{
Application of The AHP Method For Prioritizing Actions To Reduce Risk Associated With Gravitational Mass Movements In Areas Along The Margins of Watercourses of The City of Rio Branco, Brazil.
}

Ricardo Ribeiro Nascimento ( $\square$ ricardo.nascimento@ufac.br )

Universidade Federal do Acre https://orcid.org/0000-0002-0860-6133

Eduardo Antônio Marques

Federal University of Vicosa: Universidade Federal de Vicosa

Gustavo Ferreira Simões

Universidade Federal de Minas Gerais

Research Article

Keywords: Gravitational Mass Movement, AHP, Risk Mapping, Brazil

Posted Date: August 17th, 2021

DOI: https://doi.org/10.21203/rs.3.rs-705639/v1

License: (c) (1) This work is licensed under a Creative Commons Attribution 4.0 International License.

Read Full License 

ASSOCIATED WITH GRAVITATIONAL MASS MOVEMENTS IN AREAS ALONG THE MARGINS OF WATERCOURSES OF THE CITY OF RIO BRANCO, BRAZIL.

\author{
R. R. Nascimento ${ }^{\text {a }}$, E.A.G.Marques ${ }^{\text {b }}$, G. F. Simões ${ }^{c}$
}

a. Center for Exact and Technological Sciences, Federal University of Acre, Campus Universitário, Rio Branco (AC), 69.920-900, Brazil.

b. Departament of Civil Engineering, Federal University of Viçosa, Campus Universitário, Viçosa (MG), 36570-000, Brazil.

c. Departament of Sanitary and Environmental Engineering, Federal University of Minas Gerais, Av. Antônio Carlos, 6627 - Pampulha, Belo Horizonte (MG), 31270-901, Brazil. are present in different parts of the world, but in the Amazon, whose hydrological regime has unique characteristics, and whose socioeconomic situation may be considered as underdeveloped, such problems come into sharp focus. Rotational landslides and creeps on the ground are present with high frequency and magnitude in several municipalities in the Western Amazon. Such processes act in association and annually cause significant losses and material damage. In this context, this study proposes the structuring of a decision-making process that aims to assist in the indication of critical areas, as well as proposing possible actions to mitigate risks. The criteria and procedures adopted for risk-mapping in a portion of the urban center of Rio Branco-AC are described, herein. Risk was measured, based on the multicriteria analysis of attributes related to the physical, anthropic environment and the characteristics of the processes considered. The Hierarchical Analysis Method (AHP), was the technique adopted to structure the risk assessment model, which was later integrated into the GIS environment, to allow spatial analysis. The results were presented in the form of cartograms, descriptive tables and graphs, and aim to help control the mapped risks.

Keywords: Gravitational Mass Movement. AHP. Risk Mapping. Brazil. 7

In Brazil, in particular and in the world, in general, uncontrolled growth and high rates of urbanization contribute to increasing the vulnerability of the exposed population and the potential for damage to infrastructure and facilities, which makes the issue of risk assessment and analysis an essential step for the adoption of policies aimed at reducing natural disasters.

As a result, several authors and entities (Cerri et al., 2007; Faria \& Augusto Filho, 2013; Sobreira \& Souza, 2012; Nola \& Zuquette, 2021) have been developing methods and techniques (progressive detailing, experience of precedent etc.) to map risks, especially those related to external geodynamics processes.

In Brazil and in many other countries, risk mapping is based on predominantly qualitative assessments, in which the situational risk is diagnosed by the team that performs the mapping, based 
on field surveys, through surface geological-geotechnical investigations (Cerri et al., 2007; Faria \& Augusto Filho, 2013). However, more recently, several researchers (Vega \& Hidalgo, 2016; Cascini et al., 2005; Jasiwal, 2011; Nola \& Zuquette, 2021) have developed procedures to allow some quantitative risk assessment.

Observing the diversity of adverse processes (falls, landslides, creeps, inundations, flash floods etc.) and exposed elements (populations, properties and goods, economic and social activities etc.), it is possible for a specialist to understand that such a diagnosis needs to go through the evaluation of the phenomenon based on an appropriate interpretation of its controlling factors; there is a constant need to describe them in a systematic and way, compatible with the scale to be applied.

Therefore, it is essential that there is some prior knowledge about the dangerous event (its type, mechanism, material involved, magnitude, speed, trajectory, severity, destructive power etc.) and the vulnerability of the exposed element.

Even recognizing the inaccuracies and uncertainties inherent in qualitative assessments, Cerri et al. (2007) emphasize the importance of this activity for the effectiveness of an intervention policy. To improve the risk mapping approaches Faria \& Augusto Filho (2013), Vega \& Hidalgo (2016), Cascini et al. (2005) and Jasiwal (2011) consider it pertinent to suggest and incorporate quantitative techniques that can contribute to reducing subjectivity.

Although the indeterminacy of an ideal solution may be evident, since there are no unique constraints, or even a single perception of the problem, it is essential that the diagnosis made presents some level of hierarchy regarding the solutions considered and generates assistance in allowing the validation of the results. This hierarchy should be based on qualitative criteria (type of movement, characteristics of land use and occupation, construction standards etc.) and quantitative criteria (number of properties and affected population, volume that can be moved, affected area, engineering intervention costs etc.).

1 In this sense, there is the perspective that the structuring of a decision-making process, based on 2 the use of the decision support routine called Analytical Hierarchy Process - AHP, can simplify the 
valuation of the conditions, reduce inconsistencies and provide assistance that allow a more objective indication of risk situations.

The results presented in this article are related to a study developed with a focus on the indication of critical areas regarding the risk of gravitational mass movements in areas adjacent to rivers and streams in the Brazilian Amazon hydrographic system, especially creeps or rotational landslides.

This research has as its central premise the fact that the social and economic damages related to such processes (creeps and rotational landslides) are significant in areas adjacent to the water courses of Amazonian cities, and that knowledge regarding the mechanisms and principles that govern them is still incipient (Carvalho et. al., 2009; Labadessa, 2011; Matos \& Cursinho, 2012; Pacheco \& Brandão, 2012; Magalhães \& Gomes, 2013).

The perception regarding the use and occupation of land in these areas, as well as the precarious infrastructure and the lack of uniformity in the language and criteria adopted, has limited the efficiency of the strategies necessary for adequate planning and coping with risk in these spaces.

In this context, the objective of this work was the development of a procedure based on the Hierarchical Analysis Method, capable of evaluating, quantifying and hierarchizing, the conflicting relationships between the use and occupation of areas along the margins of watercourses in Amazonian cities and the magnitude of dangerous phenomena, to then indicate a set of mitigating actions.

1 The research was carried out in a test area of the urban core of Rio Branco (AC), located in the Northern region of Brazil. This area is known for presenting frequent creep movements and rotational landslides, in an area with materials with geological and geotechnical characteristics that shows high susceptibility to the occurrence of such gravitational mass movements (Maia, 2003; Oliveira \& Ferreira, 2006), in addition to occupations with different patterns and stages of consolidation. The results presented in the form of cartograms, descriptive tables and tables that aim to help control the mapped risks. 
The delimitation and assessment of areas subject to the occurrence of dangerous events and, therefore, areas with geological-geotechnical risk, depends on knowledge and surveying of the

81 attributes that influence the predisposition and outbreak of the considered processes (Sobreira \& Souza, 2012). The great challenge in this type of assessment consists in relating, in a systematic way, the characteristics of the physical environment and the anthropic actions, with the signs of movement identified to, then, indicate the potentialities and limitations of the different terrains. An important aspect to be considered with regard to the characterization of the physical environment refers to the identification of the processes responsible for the observed events, which are responsible for the appearance/creation of the areas of geological-geotechnical risk.

AHP has been applied in several areas of knowledge and has proved to be extremely useful in the analysis of geological-geotechnical risk of mass movements and in other natural disasters, especially in situations involving subjective judgments, as pointed out by the studies by Rodrigues \& Zuquete ( 2006), Paula \& Cerri (2012), Kayastha et al. (2013), Faria \& Augusto Filho (2013), Intarawichian \& Dasananda (2010). sub-criteria and alternatives, in successive levels. 


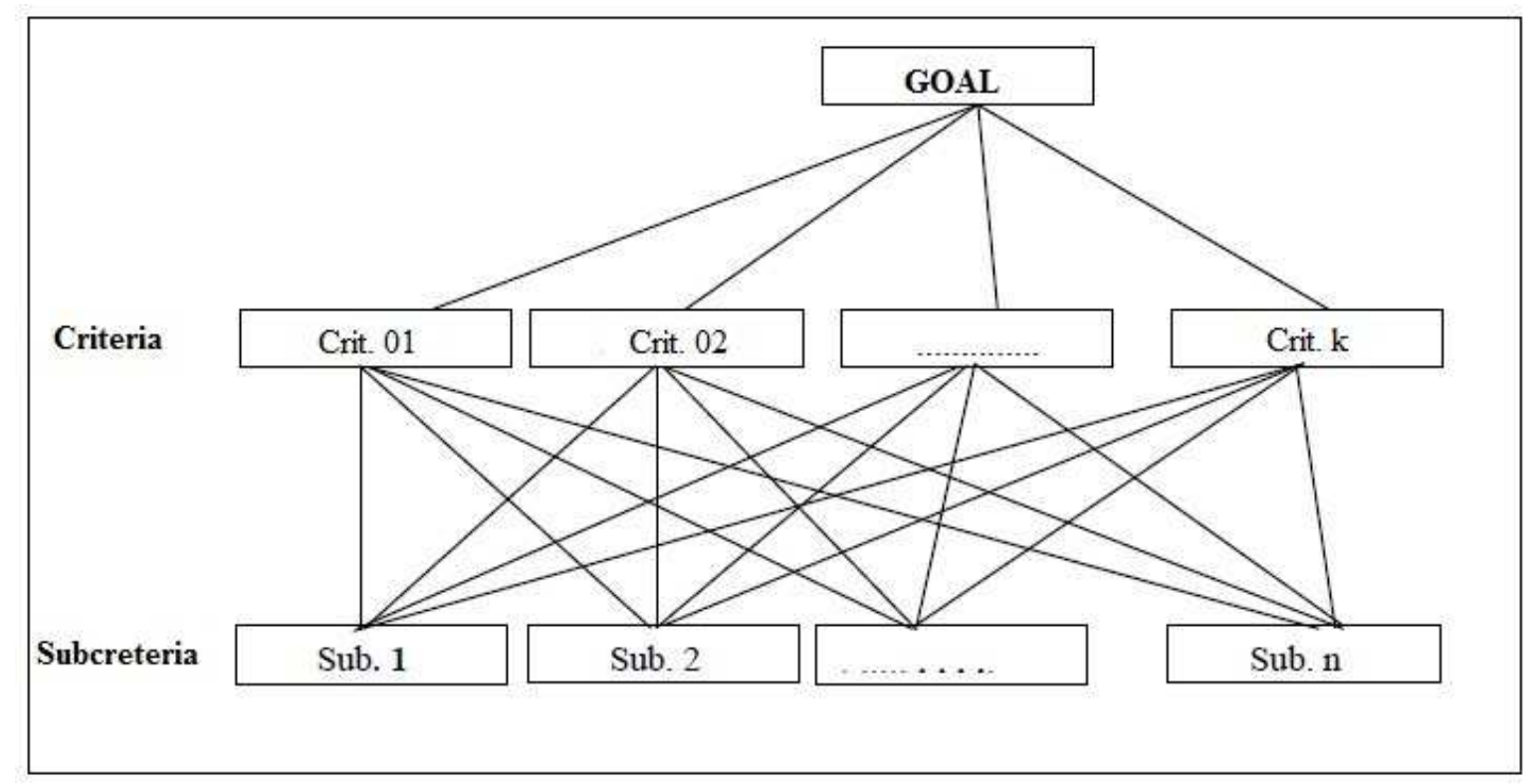

Figure 1 - Typical hierarchy structure for an AHP

Rodrigues \& Zuquete (2006) and Paula \& Cerri (2012) summarize the recommended steps for applying the method:

i. Define the problem, that is, what one seeks to know (risk, susceptibility etc.);

ii. Create a hierarchical structure, by breaking down the problem into different levels, in which the top is occupied by the goal (general objective) and the last level by the more specific elements, such as attribute classes or intervention alternatives;

iii. Build decision matrices for each level, make parity comparisons and define the relative importance of each element. Saaty (1990) proposes that the importance of one element in relation to another, be defined based on a scale that varies from 1 to 9 , where 1 refers to the elements in the matrix that present the same importance, and 9 when one element presents a higher degree of influence over another, to explain the problem;

$$
\text { iv. Check the consistency of the judgment in each matrix; }
$$

v. Obtain the vector of priorities for each matrix and perform the global assessment of the problem through the weighted linear combination of the various elements of each hierarchical level Saaty (1990). 

that its maximum eigenvalue $(\lambda \max )$ is very close to the dimension of the matrix $(n)$, results in a greater consistency of the data, insofar as how much the closer $\lambda$ max is to $n$, the more consistent the result will be (Gomes, 2009). The Consistency Index (CI) indicates how far the given value is away

121 from the expected theoretical value $\mathrm{n}$, in which this difference is measured in relation to the number of degrees of freedom of the matrix ( $\mathrm{n}-1)$. Thus, the Consistency Index is given by equation 1 . inconsistency is also verified by calculating the "Consistency Ratio" (CR) which is given by equation 2.

$$
C I=\frac{\lambda_{\max }-n}{n-1}
$$

If CI is small enough, the decision maker's comparisons are likely to be consistent. The degree of

Where RI is the random consistency index for the value n (matrix order number), which represents the value that would be obtained in a reciprocal matrix of order $n$ and in which no logical judgments were made.

More fundamentals about AHP can be found in Saaty (1977), Saaty (1980), Saaty (1990) and Saaty (2008).

\section{MATERIAL AND METHODS}

\subsection{DEFINITION OF THE STUDY AREA}

The study was applied to a portion of the urban core of Rio Branco (AC), in a representative region of areas adjacent to rivers and streams in the Western Brazilian Amazon (Figure 2), where events related to creeps and rotational landslides annually cause significant losses and material damage.

This area, with a surface area of approximately $1.1 \mathrm{~km}^{2}$, involved the city's historic center, the edge of the river Acre and five precarious settlements. It presents a sensitive diversity of densities and occupation patterns, which are inserted in the same geomorphological context (Rio Branco 
143 adequate for the simulation of different risk scenarios.

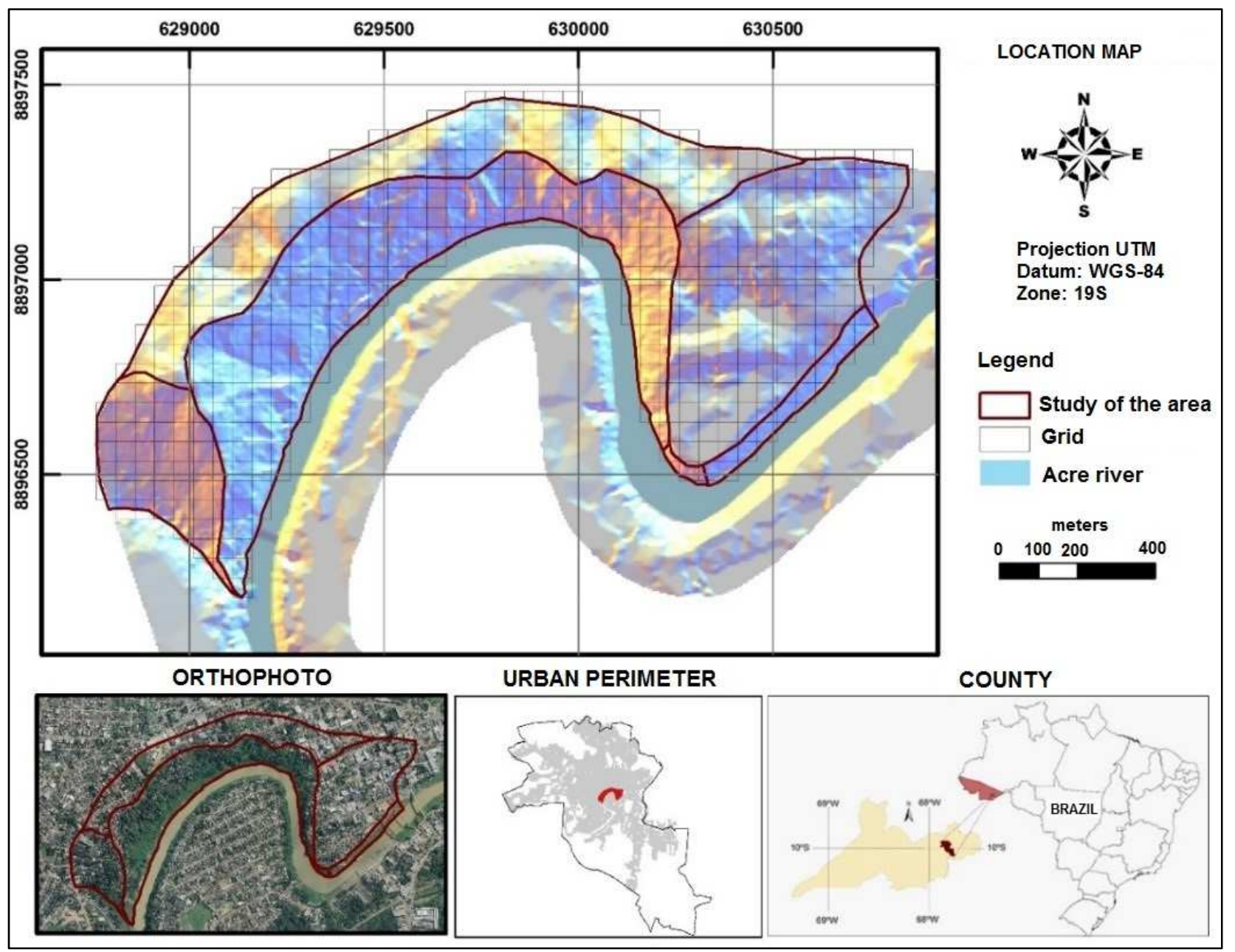

Figure 2 - Location of the study area.

144 To support the application of the proposed methodology, we initially sought to characterize the

145 types of gravitational mass movements (their typology, mechanisms and materials involved) based

146 on an integrated analysis of the components of the physical environment (relief, water courses,

147 scarring records) previous events and geological materials involved). In this context, two ranges of

148 land adjacent to the main water courses in the urban area of Rio Branco, the Acre River and one of

149 its tributaries, the São Francisco stream, were selected for this activity.

150 Through the use of techniques for physiographic compartmentalization of land and field work,

151 which involved the registration and the geological-geotechnical characterization of 73 features of 152 instability, the geotechnical zoning presented in Figure 3 was obtained, the steps, criteria and 
153 procedures of which were used in its construction are detailed in Nascimento (2016) and Nascimento

154 \& Simões (2017).

155 Based on the geological characteristics (type of geological material present), geotechnical (areas

156 subject to flooding, material parameters etc.) and geomorphological (longitudinal shape of the

157 margin) of each compartment, and considering the register of events that occurred in them (including

158 position and frequency), the degrees of susceptibility to the occurrence of new events were defined.

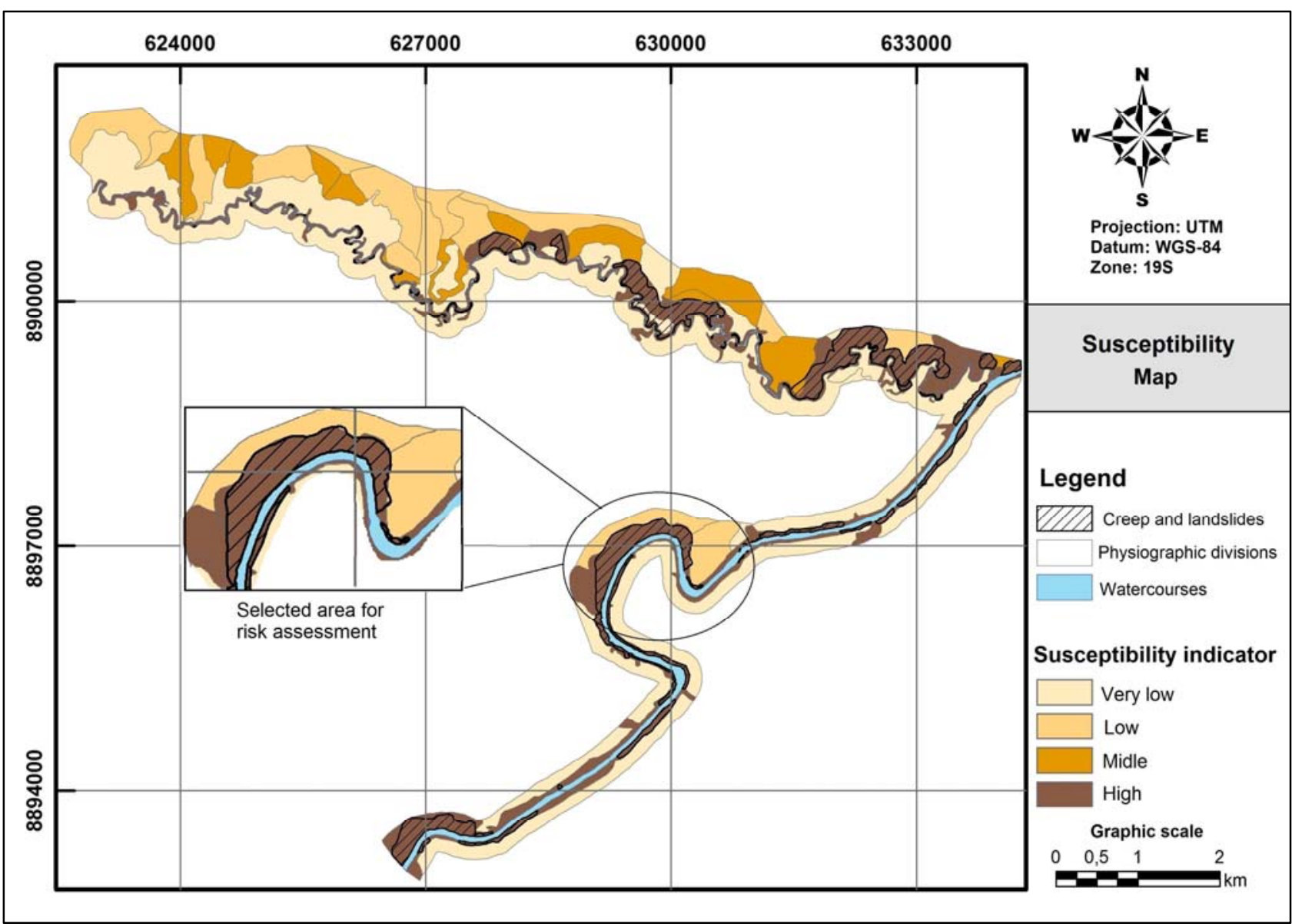

Figura 1 Geotechnical zoning of mass movements susceptibilty.

Source: Nascimento (2016).

159 The mapping work was carried out by Nascimento (2016), in the zoning phase, which allowed us

160 to infer that creeping and rotational slides are the most significant processes, both by the frequency

161 with which they occur and by the magnitude of the registered events. 
The creeps are associated with the plastic soils that cover the hills of the Solimões Formation,

163 occur more frequently in terrain with a slope greater than $12 \%$ and are not limited to the flooded 164 section of the channels.

165 According to Nascimento (2016), rotational landslides are frequently observed in flooded areas 166 and also on slope surfaces already weakened by the creep, which are often induced by the intense 167 fluctuations of river discharges that coincide with periods of intense and prolonged rain. There are 168 depressions between 0.4 and $2.2 \mathrm{~m}$ high and traction cracks that are hundreds of meters long at the top 169 and mid-slope. The evidence of creeping is widespread, with an increase in its rate of displacement 170 in the rainiest quarter, evidenced by the misalignment of the foundations of wooden buildings, as can 171 be seen in Figure 4. The movements take place in predominantly clay-silty soils, as described in 172 Figure 5, which represents section $\mathrm{AB}$ (indicated in Figure 4), which was adapted from the work of 173 Nascimento (2016).

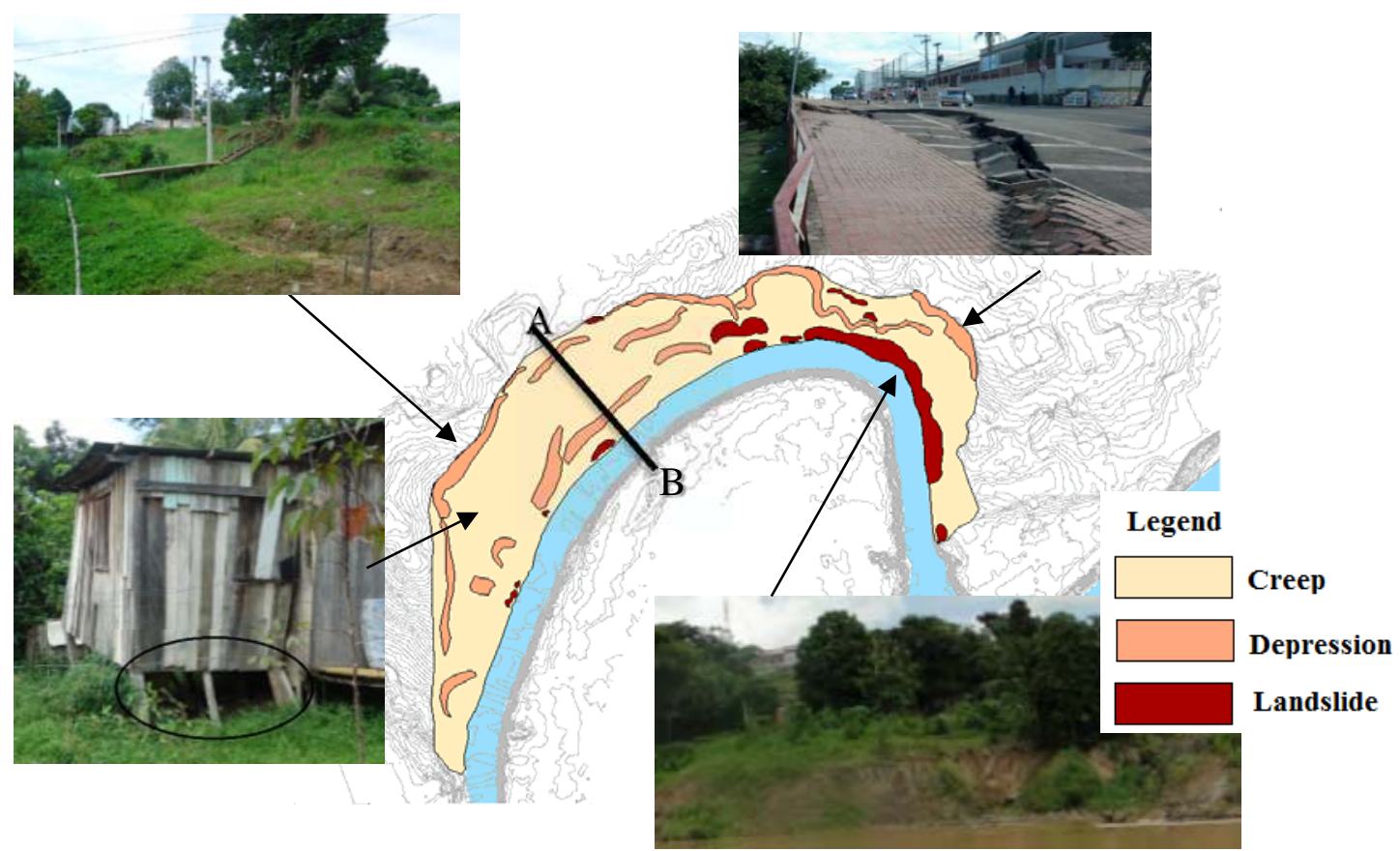

Figure 4 - Aspects and evidences of instability of mass movements registered by Nascimento (2016). 


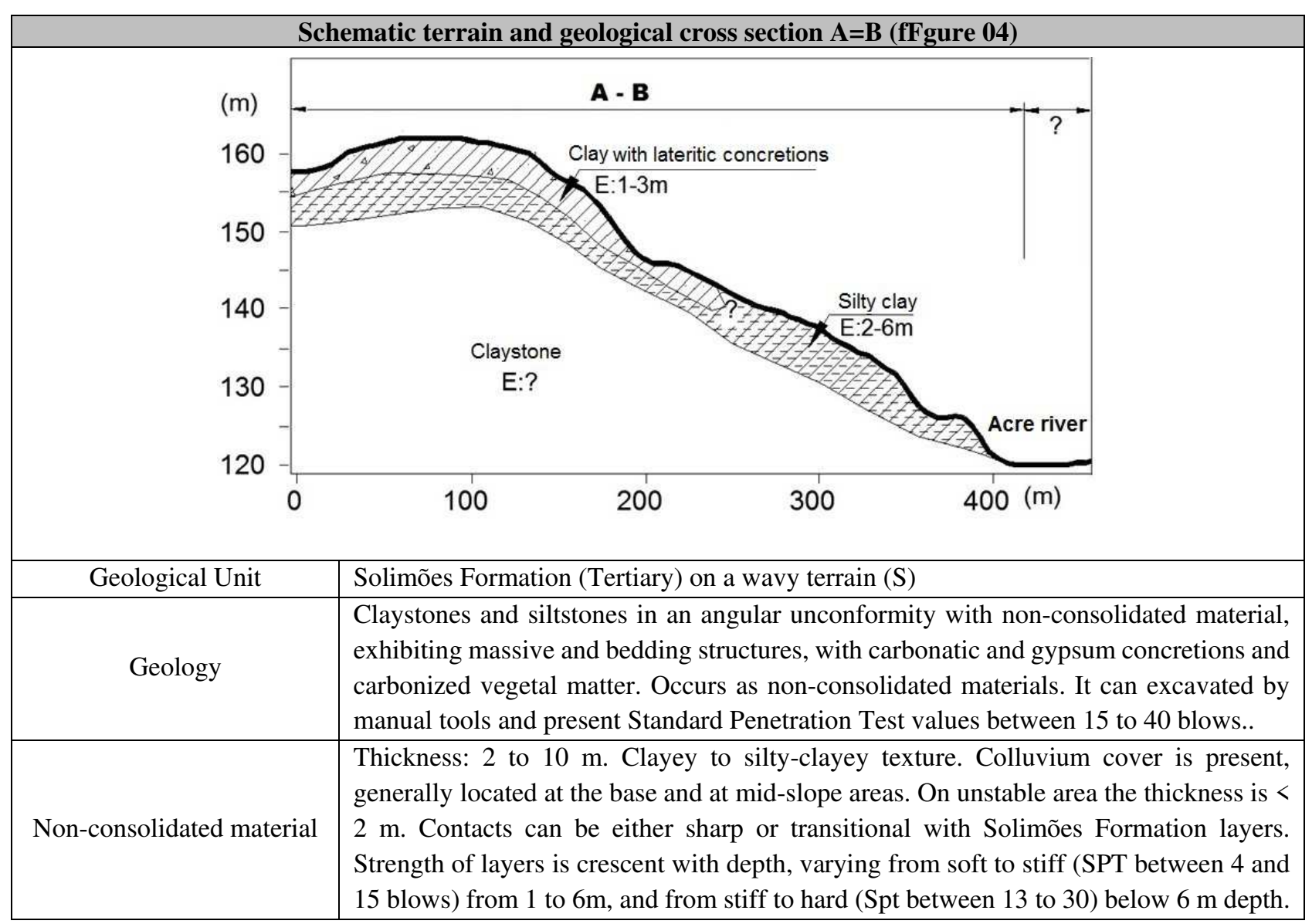

Figure 5 - Summary of physical characteristics observed in the study area by Nascimento (2016).

\subsection{MATERIALS}

The basic reference information obtained in this research comes from the Territorial Information System (SITgeo) belonging to the Municipality of Rio Branco, whose database is from 2013. The main materials obtained from SITgeo were:

- Digital mosaic of aerial photography from 2013, with a spatial resolution of 5 meters, on a scale of 1:5000, developed by Aeroimagem S/A and obtained through a digital aerophotogrammetric camera - LEICA ADS-80;

- Digital topographic map of the urban area, with contour lines equidistant at one meter on a scale of 1: 5000, obtained by airborne laser profiling, in 2013;

- Registry map on a scale of 1: 5000, from the year 2013, containing information regarding plans for public places, lots, paved roads, land use, rivers, neighborhoods and flood zones;

- Fluviometric data from 1970 to 2014 provided by the State Civil Defense Coordinator; 
- Geotechnical zoning database for susceptibility to gravitational mass movements developed by

187 Nascimento (2016): shape files, topographical and geological feature records, field records, geological-geotechnical sections and 23 standard penetration test logs; and

- Google Street View images from the year 2012.

190 The Geographic Information System (GIS), of the ArcGIS 9.3 program, an ArcMap operations

191 module developed by ESRI, was the tool used to manipulate all available or generated information 192 plans. This took place by using projection "Universal Transversa de Mercator" - UTM, WGS-84, 193 zone 19S.

\subsection{STEPS AND METHODOLOGICAL PROCEDURES}

The following is a detailed description of the methodological procedures used in carrying out the work.

\subsubsection{E1 - Definition of the land unit}

In general, the susceptibility maps provide important aid in planning the occupation of territorial space, especially with regard to the potential of a region's physical environment for the development of a given process.

However, it must be understood that these cartographic products have limitations related to the definition of actions necessary to mitigate geological risks and natural disasters. For there to be an indication of where, and what actions will be necessary to face the risk, in the short and medium term, 204 it is necessary that the study be conducted on a higher, more detailed, scale, which in addition to the natural terrain susceptibility, also considers the degree of development of the processes and their relationship with anthropic induction factors and the vulnerability of the exposed elements.

208 processes and their stages of development, it was decided to select a regular area, named cells, with 209 dimensions of 50 by 50 meters, to represent the smallest unit of risk mapping, which allowed the 210 tabulation and cross-indexing of information related to the criteria defined within the AHP 
211 systematics, without the concern of overestimating or underestimating the extent of each evaluated 212 criterion.

213 The study area was, therefore, subdivided into 467 cells that constituted the information plan called 214 Regular Grid. This information plan was generated in vector format, in the ArcGis program, using 215 the Vector Grid operator of the GeoWizard 11.2 extension.

To tabulate the information related to the classes of the evaluated attributes, the table of attributes of the information plan of the Regular Grid was organized in a similar way to the example presented in Table 1.

\begin{tabular}{|c|c|c|c|c|}
\hline $\begin{array}{c}\text { Cell } \\
\text { (code) }\end{array}$ & Attribute 1 & Attribute 2 & Attribute 3 & Attribute $n$ \\
\hline Cell 1 & Class $A_{1}$ & Class $\mathrm{A}_{2}$ & Class $\mathrm{A}_{3}$ & Class $A_{n}$ \\
\hline Cell 2 & Class $\mathrm{B}_{1}$ & Class $\mathrm{B}_{2}$ & Class $\mathrm{B}_{3}$ & Class $B_{n}$ \\
\hline Cell $n$ & Class $\mathrm{C}_{1}$ & Class $\mathrm{C}_{2}$ & Class $C_{3}$ & Class $C_{n}$ \\
\hline
\end{tabular}

\subsubsection{E2 - Risk Breakdown}

217 The decision problem (risk assessment) was broken down into four levels of hierarchy, as can be 218 seen in Figure 6. The first level was occupied by the components that determine the risk in the land 219 unit, that is, the Hazard Index (HI ) and the Vulnerability Index (VI); the second level was composed of the indicators of these components (Natural Susceptibility, Potential of Induction, Potential of Destruction, Degree of Resilience and Potential of Damage); the third level was made up of the attributes (natural, anthropic and process characteristics); and the fourth level, and last one, by the classes of each attribute.

The susceptibility indicator was obtained by overlapping the Zoning Information plan with the Regular Grid information plan. Although this indicator allows estimating favorable or unfavorable characteristics to the development of the considered processes, the presence of signs of movement in a given cell may indicate that it already has all the characteristics necessary for the development of a geological mass movement. 


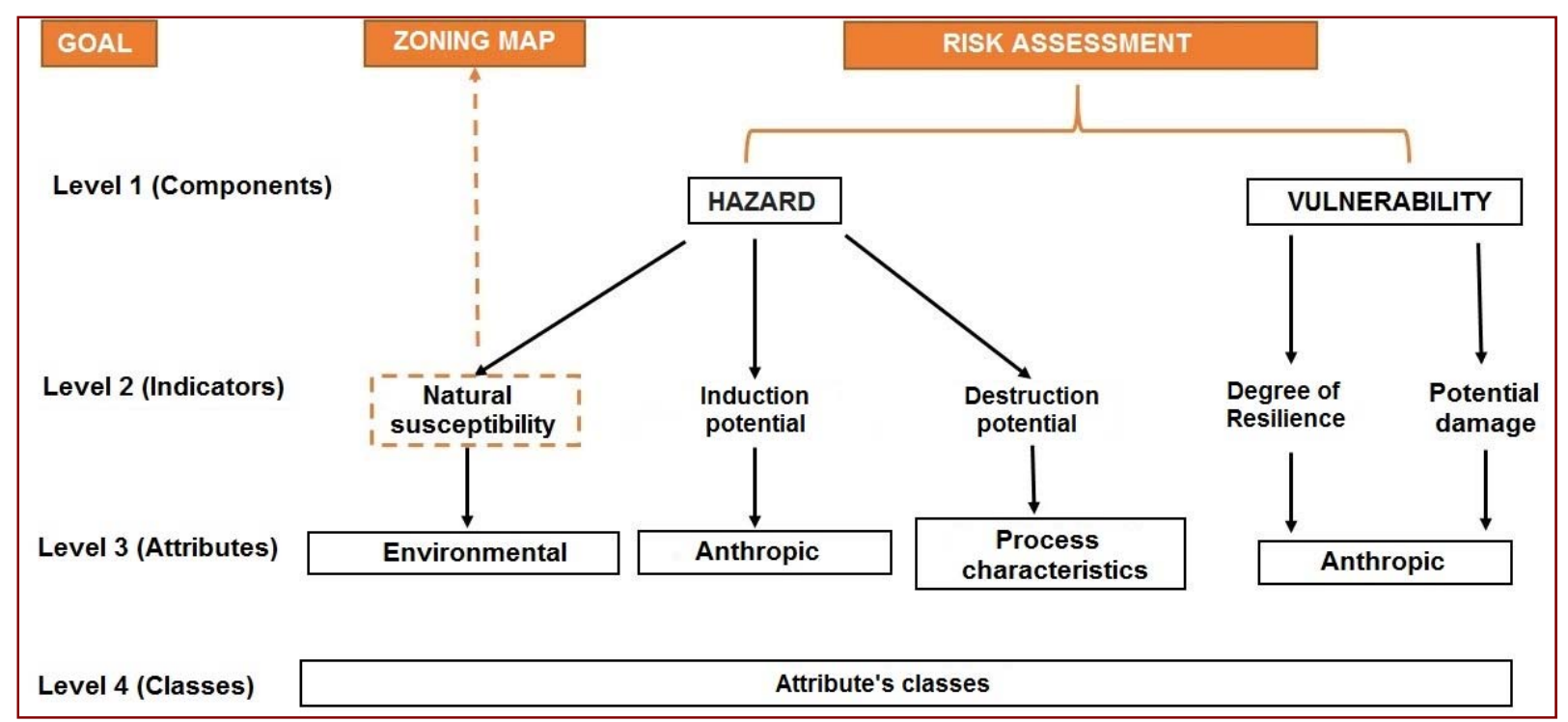

Figure 6 - Adopted hierarchy structure.

229 In this case, the quantification of the hazard must consider the level of development of the process, 230 which can be estimated based on signs of movement identified through fieldwork.

231 The information related to the signs of movement was obtained based on overlaps between the 232 shapefile of Regular Grid, with the registration of unstable areas carried out by Nascimento (2016); 233 the contour lines with a frequency of $1 \mathrm{~m}$ and the orthophoto of 2013 . This allowed identification of 234 rugged regions, landslide features and those areas with evidence of creeping. The level of 235 development of the mapped signs and evidences was based on the information contained in 236 Nascimento (2016) field records.

237 The record of these occurrences in the geographic database was carried out by inserting a column 238 for each attribute related to the characteristics of the mapped processes, in the information plan of 239 Regular Grid. The magnitude of the evidence and the area of influence of these signals in the cell 240 were considered as necessary attributes to estimate the Potential of Destruction indicator.

241 The magnitude of the signs of movement was assessed based on criteria presented by Cerri et al. 242 (2007), as follows:

243 - Absent - there is no evidence of the development of instability processes;

244 - Incipient - evidence of instability suggests that the process is in an early stage, develops slowly 245 or is dormant. In this case, monitoring is perfectly possible; 
- Significant - there are indications that the process is in full development. There are diverse 247 abatement measures, cracks in the terrain and / or in buildings, or even scars from past landslides. 248 Monitoring of the area is still possible, but it is perfectly likely that landslides will occur during 249 intense episodes of rain and / or sudden variations in level in the watercourses; and

- Severe - the evidence or features of instability are expressive, indicating that landslides may occur at any time, and it is not possible to monitor them.

For the evaluation of the area occupied by the signs or features of instability in the cell the following classes were defined: absent; $<25 \% ; 25$ to $50 \%$; 50 to $75 \% ; 75 \%$ to $100 \%$.

From a different perspective, with the intention of estimating the interference of human action in area occupied by buildings and infrastructure, occupation pattern, surface water concentration, concentration of garbage / rubble on slope or escarpment and ground cover).

The information used for tabulation of classes related to anthropic attributes was obtained through 262 fieldwork and from orthophoto of 2013, information plans from the SitGeo database (lots, places, 263 buildings and road system) and Google Street View images from the year 2012. In Figure 7 there are images that illustrate some of these observations. 


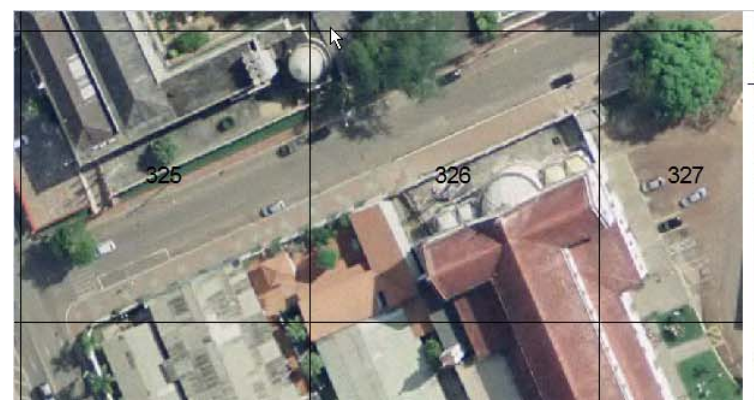

Planned ocuppation, high pattern and wellstructure occupation.

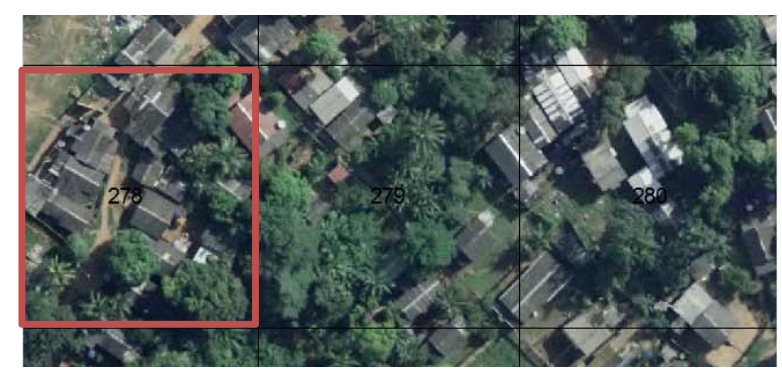

Spontaneous occupation with poor pattern in an incipient infra-structured area

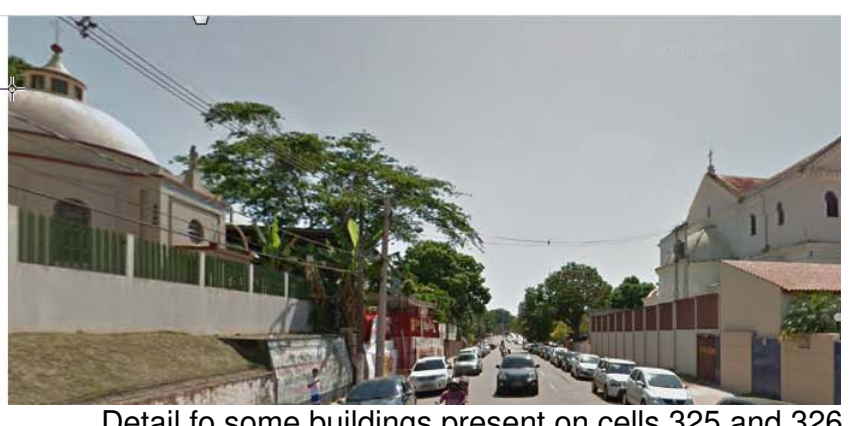

Detail fo some buildings present on cells 325 and 326 (Google StreetView, 2012).

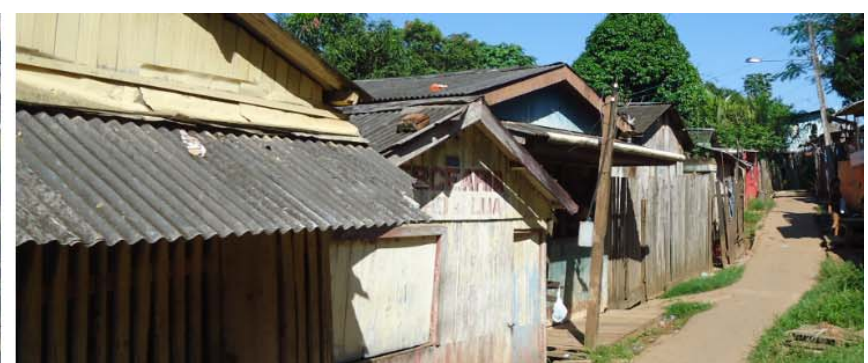

Detail of buildings present on cell 278

Figure 7 - Images that illustrate the method used for gathering information of anthropic attributes.

\subsubsection{E3 - Valuation of risk}

In this stage of application development, the comparison matrices were set up for each of the levels mentioned and represented in Figure 6. Then, comparisons were made between the elements of the same hierarchical level, with respect to the element of the higher level, defining, within a pre-defined scale of values (Table 2), the relative importance of a given element in relation to another.

In the peer-to-peer comparison, the weights of the elements of each matrix were defined by calculating the "given vector" or "priority vector", while the verification of the coherence of the judgments was performed based on the results of the "given value" calculation.

The judgments made are essentially related to the authors' experience, aided by consultations with specialists in the region studied.

To obtain the normalized weights, the maximum given value, the consistency ratio (CR) and the consistency index (CI), we used the APH module, from the ASSISTAT 7.7 statistical program (Silva and Azeredo, 2009), using as input data the comparisons made in each matrix. 
Table 2 - Scale of relative importance between factors.

\begin{tabular}{c|c|c}
$\begin{array}{c}\text { Numerical } \\
\text { Values }\end{array}$ & Terms & Comments \\
\hline 1 & Equal importance & Both factors equally contribute to the event occurrence \\
\hline 3 & Moderate importance & One factor is slightly favored when compared to other to event occurrence \\
\hline 5 & Strong importance & One factor is strongly favored when compared to other to event occurrence \\
\hline 7 & Very strong importance & One factor is very strongly favored when compared to other to event occurrence. \\
This influence can be observed in practice
\end{tabular}

The parameter adopted to assess the consistency of the judgment made, was the Consistency Ratio with a value less than 0.1 (Saaty, 1990).

The values obtained in the priority vector of each matrix corresponded to the normalized relative weights assigned to each of the evaluated elements (classes, attributes, indicators and components).

After the tabulation of the attribute classes was completed, the Attribute Table of the Regular Grid information plan was exported to Microsoft Excel. Then, a spreadsheet was created containing the standardized weights of all attribute classes. With the aid of the Microsoft Excel VLOOKUP function, the attribute class contained in each cell was converted to its normalized relative weight.

The hazard (HI) and vulnerability (VI) indexes were obtained through the linear combination between the weights of the classes, attributes and indicators, according to equation 3.

$$
I C=\sum_{i=1}^{n} R W I_{i} x R W A_{i} x R W C_{i}
$$

Where: IC is the component's value (hazard or vulnerability) in cell i; RWI: normalized relative weight of the indicator present in cell $\mathrm{i}$; RWA: normalized relative weight of the attribute in cell i; 291 RWC: normalized weight of the attribute class present in cell i; n: refers to the number of criteria.

The columns of the Excel spreadsheet that contained the values of HI and VI were inserted in the 293 table of attributes of Regular Grid and they were later converted to the matrix format, for subsequent 294 overlaps. 
This procedure was performed using the Spatial Analyst module (Feature to Raster) from the

296 ArcGis program. Subsequently, in the ArcGis program, the HI and VI values were divided into four 297 different ranges (Natural Breaks option), representing, in ascending order, the low, moderate, high 298 and very high classes for each component.

299 The results of this classification generated the Hazard and Vulnerability cartograms, which were 300 validated through the overlay of the orthophoto of 2013, the digital topographic map of the study 301 area, and to the register of instability features (Nascimento 2016), based on the scenarios presented in Table 3 and Table 4.

Table 3 - Expected scenario for each hazard class.

\begin{tabular}{|c|l|}
\hline $\begin{array}{c}\text { Hazard } \\
\text { Classes }\end{array}$ & \multicolumn{1}{c|}{ Definition } \\
\hline Low & It is unlikely that a destructive event occur in a one-year period. \\
\hline Medium & $\begin{array}{l}\text { Hazard indicators are of medium potential to destructive processes. Building } \\
\text { occupation and Consolidation of occupation should be carefully evaluated. The need } \\
\text { for specific geotechnical design and monitoring must be adopted for high } \\
\text { vulnerability areas. }\end{array}$ \\
\hline High & $\begin{array}{l}\text { Hazard indicators are of high potential, in way that the occurrence of an event sis } \\
\text { very likely to occur in one-year period. New occupation areas, including buried } \\
\text { infrastructure must be avoided. Monitoring must be constant and preferably } \\
\text { performed by using instrumentation on more vulnerable units. }\end{array}$ \\
\hline Very High & $\begin{array}{l}\text { There are general evidences of creep and rotational mass movements. It is not } \\
\text { possible to predict when new movements will occur. }\end{array}$ \\
\hline
\end{tabular}


Table 1 - Probable scenarios explanation for each vulnerability classes.

\begin{tabular}{|c|l|}
\hline $\begin{array}{c}\text { Vulnerability } \\
\text { Classes }\end{array}$ & \multicolumn{1}{c|}{ Definition } \\
\hline Low & $\begin{array}{l}\text { Formed by non-occupied areas (buildings and infrastructure). Even if an event } \\
\text { occur, it is unlikely that associated damage will occur. }\end{array}$ \\
\hline Medium & $\begin{array}{l}\text { Composed by open areas and areas with low consolidation levels. Damage } \\
\text { associated with the occurrence of a event are of moderate severity. }\end{array}$ \\
\hline High & $\begin{array}{l}\text { Composed by consolidated or under consolidation areas. Damage associated to the } \\
\text { occurrence of one instability process can result in human and material losses. }\end{array}$ \\
\hline Very High & $\begin{array}{l}\text { Composed by consolidated or under consolidation areas. Damages associated to the } \\
\text { occurrence of one instability process are significant and are essentially related to the } \\
\text { population high fragility occupying these areas. }\end{array}$ \\
\hline
\end{tabular}

The values of HI and VI were divided into four classes (low, moderate, high and very high), using 304 the Natural Breaks function, from ArcGis. The risk evaluation (RI) resulted from the combination of 305 these classes and was obtained through equation 4:

$$
R I=H I x V I(4)
$$

Where: RI is degree of risk in cell $\mathrm{i}$; HI: weight of the class of the hazard component present in cell $\mathrm{i}$; VI is the weight of the class of the vulnerability component present in cell $\mathrm{i}$.

309 The risk in a given cell was conditioned to the mutual existence of hazard and vulnerability. If 310 there is no propensity for damage to occur due to a particular physical event, there is no hazard and, 311 therefore, there is no risk. In order for this relationship to be translated into numerical terms, the 312 matrix shown in Table 5 was constructed.

313 In this sense, it was considered that risk situations only exist when one of these components is not 314 incipiently present, which is why a scale of 0 to 3 was defined. 
Table 5 - Risk matrix

\begin{tabular}{|c|c|c|c|c|c|}
\hline & \multicolumn{5}{|c|}{ Hazard (Score) } \\
\hline \multirow{5}{*}{ 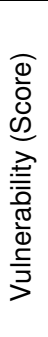 } & $\mathrm{RI}=\mathrm{HI} \times \mathrm{VI}$ & Low (0) & Moderate (1) & High (2) & $\begin{array}{c}\text { Very High } \\
\text { (3) }\end{array}$ \\
\hline & Low (0) & 0 & 0 & 0 & 0 \\
\hline & Moderate (1) & 0 & 1 & 2 & 3 \\
\hline & High (2) & 0 & 2 & 4 & 6 \\
\hline & Very high (3) & 0 & 3 & 6 & 9 \\
\hline & Low & \multicolumn{2}{|c|}{ Moderate } & High & \\
\hline
\end{tabular}

315 The RI equal to 0 (low risk) indicates the least critical condition, in which, by maintaining the 316 existing conditions, the possibility of social or economic damage is minimal, as it is unlikely that the 317 event will occur, or due to the condition of low vulnerability of the exposed element. Areas with a 318 low degree of hazard were considered to be stable.

319 The RI of 1 to 3 (moderate risk) indicates that, if the existing conditions are maintained, it is 320 perfectly possible that social or economic losses will occur, especially in the months of more intense 321 rainfall. It is, therefore, recommended to relocate buildings located in areas with a high or very high 322 degree of hazard and to monitor those with a moderate threat potential.

323 The RI greater than 3 (high risk) indicates the most critical condition. The signs of instability are 324 expressive, in number and / or magnitude. If the existing conditions are maintained, events with high 325 destructive power are very likely to occur. Due to the conditions of vulnerability, significant social 326 and economic damage is expected in these areas, which is why it is recommended to relocate the 327 buildings that are present there.

328 Considering the situations described, it is considered extremely important that, concurrent with 329 defining the degree of risk, the type of action and some deadline for its execution should also be 330 defined.

331 The decision on the type of action and the respective deadline resulted from the cross-indexing the 332 level of risk and the degree of hazard, as follows:

333 - Do not intervene - low risk and low hazard; 
- Do not occupy - low risk and medium, high or very high hazard;

335 - Monitoring - moderate or high risk and medium hazard;

336 - Monitoring with scheduled relocation - moderate or high risk and high hazard;

337 - Immediate relocation - high risk and very high hazard.

\section{RESULTS AND DISCUSSION}

340 Considering the proposed system, the relative normalized weights for indicators (RWI), attributes 341 (RWA) and classes (RWC) were defined using the AHP method, which were later related by means 342 of a linear combination to support the evaluation of the risk components (HI - Hazard Index and VI 343 Vulnerability Index). The results of which are summarized in Table 6.

Table 6 - Indicators, classes and respective weights obtained throughout AHP for all components.

\begin{tabular}{|c|c|c|c|c|c|c|}
\hline Comp. & Ind. & $\begin{array}{l}\mathrm{RWI} \\
(\%)\end{array}$ & Attibutes & $\begin{array}{c}\text { RWA } \\
(\%)\end{array}$ & Classes & $\begin{array}{c}\text { RWC } \\
(\%)\end{array}$ \\
\hline \multirow{8}{*}{ 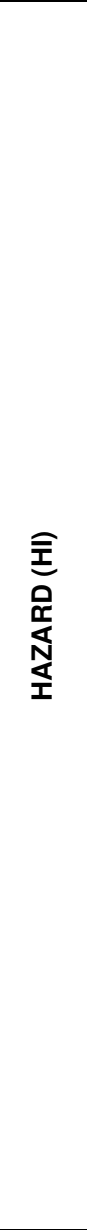 } & 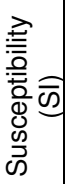 & 38.79 & $\begin{array}{l}\text { Characteristics and behaviours of } \\
\text { geological-geotechnical mapped } \\
\text { units (Nascimento, 2016) }\end{array}$ & 100.00 & $\begin{array}{l}\text { High } \\
\text { Medium } \\
\text { Low }\end{array}$ & $\begin{array}{l}61.52 \\
31.88 \\
6.60\end{array}$ \\
\hline & \multirow{3}{*}{ 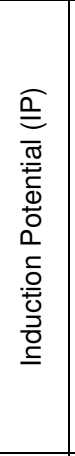 } & \multirow{3}{*}{14.26} & Soil cover (SC) & 25.00 & $\begin{array}{l}\text { Vegetal } \\
\text { Urban } \\
\text { Mixed }\end{array}$ & $\begin{array}{l}7.96 \\
65.56 \\
26.48 \\
\end{array}$ \\
\hline & & & $\begin{array}{l}\text { Waste deposits on slope or cliffs } \\
\text { (DS) }\end{array}$ & 25.00 & $\begin{array}{l}\text { Very low or absent } \\
\text { Low } \\
\text { Medium } \\
\text { High }\end{array}$ & $\begin{array}{c}5.72 \\
11.01 \\
30.79 \\
52.48\end{array}$ \\
\hline & & & $\begin{array}{c}\text { Superficial water concentration } \\
\text { due to leakage of sewage and } \\
\text { water pipe system or absence of } \\
\text { such systems (WS) }\end{array}$ & 50.00 & $\begin{array}{l}\text { Very low or absent } \\
\text { Low } \\
\text { Medium } \\
\text { High }\end{array}$ & $\begin{array}{l}5.14 \\
12.87 \\
23.33 \\
58.66\end{array}$ \\
\hline & \multirow{4}{*}{ 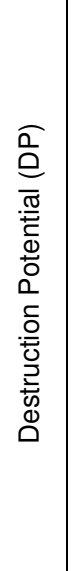 } & \multirow{4}{*}{46.95} & $\begin{array}{l}\text { Areas with instability signs } \\
\qquad(\mathrm{Al})\end{array}$ & 40.00 & $\begin{array}{c}\text { No evidence } \\
<25 \% \\
25 \text { a } 50 \% \\
50 \text { a } 75 \% \\
75 \text { a } 100 \% \\
\end{array}$ & \begin{tabular}{c|}
3.57 \\
9.89 \\
16.01 \\
26.38 \\
44.15 \\
\end{tabular} \\
\hline & & & \multirow{3}{*}{ Events magnitude (EM) } & \multirow{3}{*}{60.00} & $\begin{array}{l}\text { Absent } \\
\text { Incipient (processes develops slowly and is possible } \\
\text { to monitor) }\end{array}$ & $\begin{array}{r}4.66 \\
12.84\end{array}$ \\
\hline & & & & & $\begin{array}{l}\text { Significant (process is under full development and it is } \\
\text { possible to monitor, but it is possible that mass } \\
\text { movements occur during heavy rain periods or due to } \\
\text { variations on drainage levels) }\end{array}$ & 29.65 \\
\hline & & & & & $\begin{array}{l}\text { Severe (High potential for mass movements to occur. } \\
\text { It is not possible to monitor) }\end{array}$ & 52.85 \\
\hline
\end{tabular}


Table 6 - Indicators, classes and respective weights obtained torughout AHP for all components (Continuation).

\begin{tabular}{|c|c|c|c|c|c|c|}
\hline \multirow{4}{*}{ 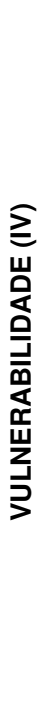 } & \multirow{2}{*}{ 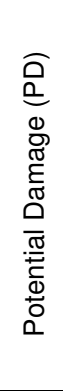 } & \multirow[t]{2}{*}{20.00} & Occupation Pattern (OP) & 50.00 & $\begin{array}{c}\text { High } \\
\text { Medium } \\
\text { Low } \\
\text { Very Low } \\
\text { No Construction and Infrastructure }\end{array}$ & $\begin{array}{r}43.42 \\
28.24 \\
16.38 \\
8.50 \\
3.46\end{array}$ \\
\hline & & & $\begin{array}{l}\text { Area occupied by buildings and } \\
\text { infrastructure }(A O)\end{array}$ & 50.00 & $\begin{array}{c}<5 \\
5-30 \\
30-60 \\
60-100\end{array}$ & $\begin{array}{c}6.04 \\
16.23 \\
28.79 \\
48.94\end{array}$ \\
\hline & \multirow{2}{*}{ 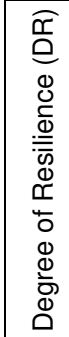 } & \multirow{2}{*}{80.00} & Construction Quality (CQ) & 50.00 & $\begin{array}{c}\text { No or precarious infrastructure } \\
\text { Some structures present } \\
\text { Well structured } \\
\text { No construction }\end{array}$ & $\begin{array}{l}51.27 \\
28.48 \\
15.95 \\
4.30\end{array}$ \\
\hline & & & Occupation Type (OT) & 50.00 & $\begin{array}{c}\text { Subnormal urban agglomerate (slams, invasions etc.) } \\
\text { Residential and commercial areas } \\
\text { Open areas } \\
\text { No construction }\end{array}$ & $\begin{array}{c}52.86 \\
33.72 \\
8.47 \\
4.95 \\
\end{array}$ \\
\hline \multicolumn{7}{|c|}{ EQUATIONS ADOPTED FOR DEFINING VALUES FOR INDICATORS AND COMPONENTS } \\
\hline \multicolumn{5}{|c|}{$H I=0.3879 I S+0.4695 D P+0.1426 I P$} & \multicolumn{2}{|l|}{$V I=0.8 D R+0.2 P D$} \\
\hline \multicolumn{5}{|c|}{$D P=0.6 E M+0.4 A I$} & \multicolumn{2}{|l|}{$D R=0.5 C Q+0.50 T$} \\
\hline \multicolumn{5}{|c|}{$I P=0.5 W S+0.25 D S+0.25 S C$} & \multicolumn{2}{|l|}{$P D=0.5 O P+0.5 A O$} \\
\hline
\end{tabular}

344 Figure 7 illustrates the overlapping of the geotechnical zoning information plan developed by

345 Nascimento (2016) with the Regular Grid information plan. Approximately 53\% of the assessed area

346 was classified as having high susceptibility and the remaining regions as having low susceptibility.

347 According to Nascimento (2016), high susceptibility is related to the slope of the compartments,

348 which varies between 12 and $20 \%$ and the fluctuations of fluvial discharges, which act directly on the

349 unconsolidated sediments and clay from the Solimões formation, generating several features of

350 instability, as described. The regions with low susceptibility are above the flood zone, in

351 compartments whose slope varies between 6 and $12 \%$.

352 In Figure 9 and Figure 10, the cartograms related to the vulnerability and hazard components are

353 presented, respectively. 


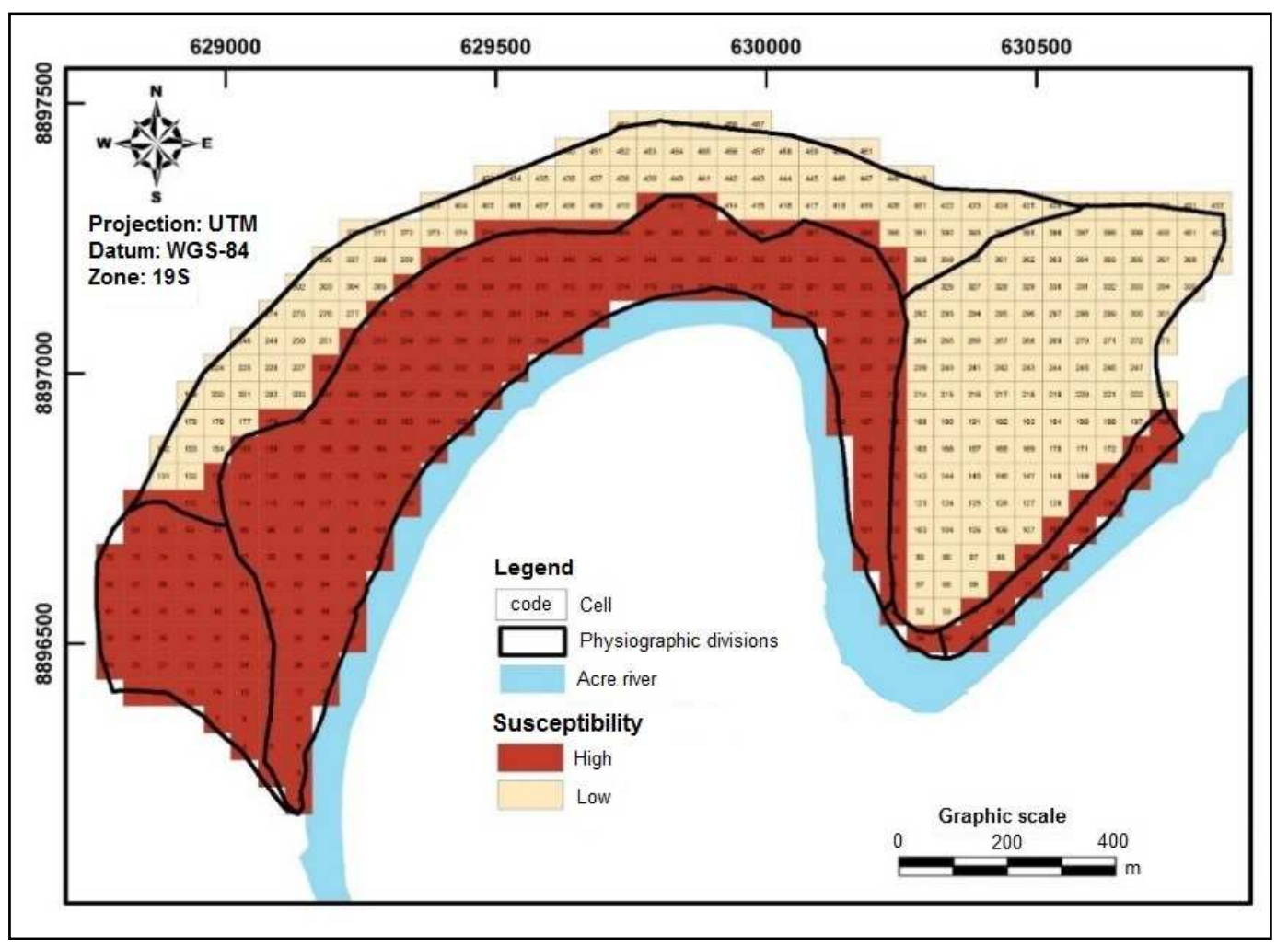

Figure 8 - Regular Grid mesh with the overlapping of susceptibility classes defined for the area studied.

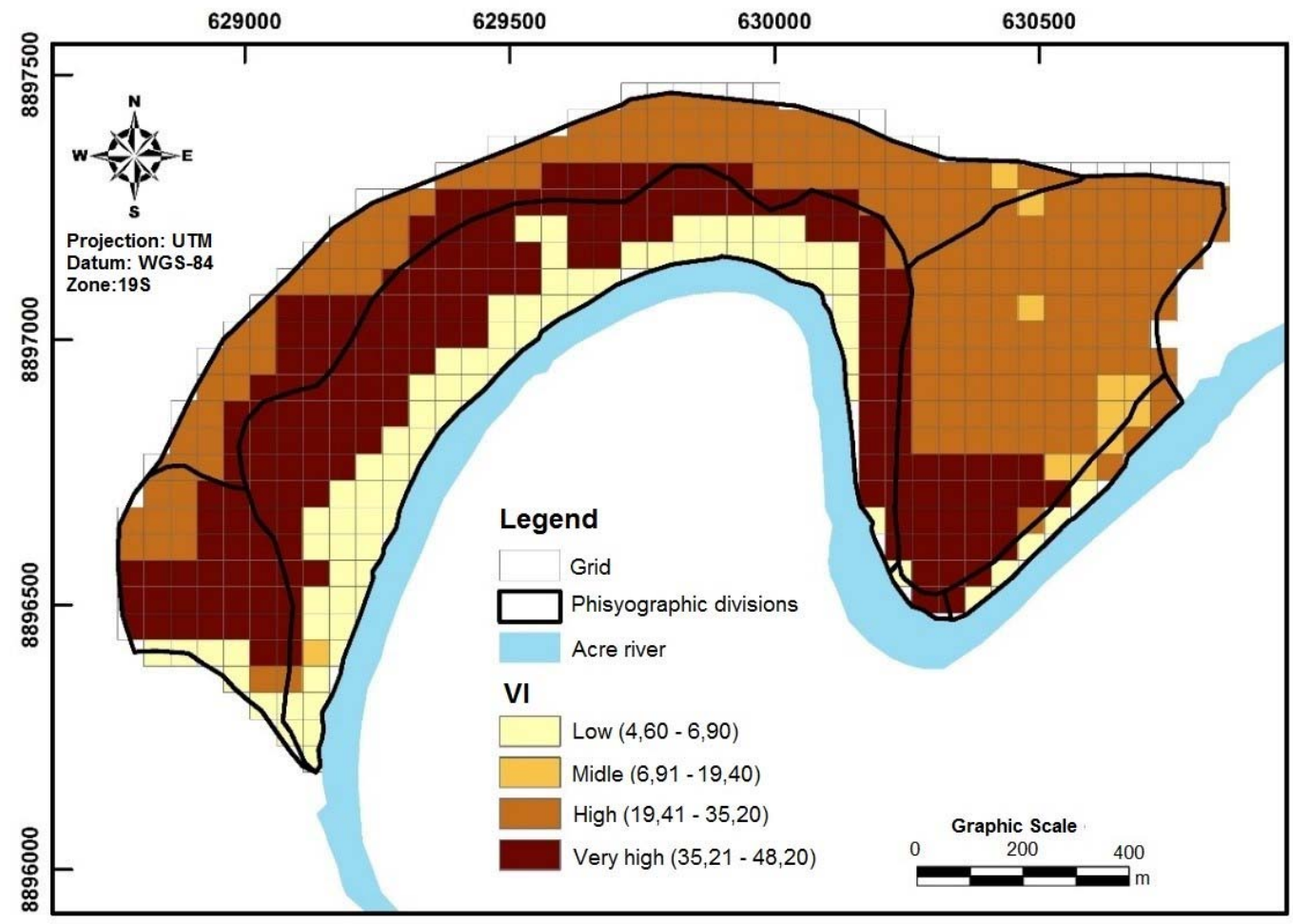

Figure 9 - Vulnerability chart. 


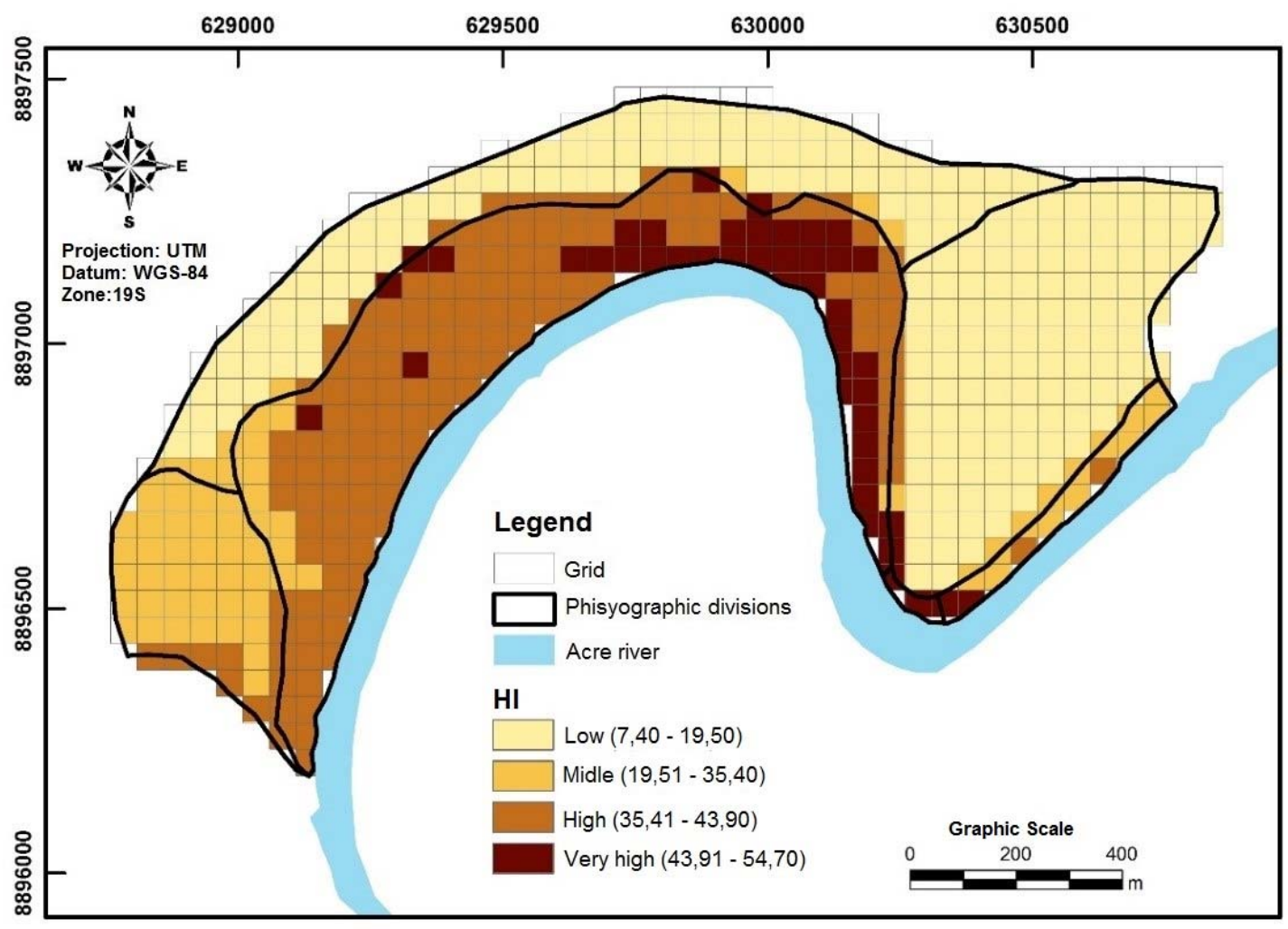

Figure 10- Hazard chart.

The simulation carried out indicated that $79.87 \%$ of the investigated area has a high and very high vulnerability to the processes considered, as can be seen in Figure 11. An indication of very high vulnerability, in general, was associated, by the risk assessment model, to regions with a high concentration of subnormal settlements. There is, also, high vulnerability, on the other hand, of the historic and administrative center of the city, characterized by well-structured buildings and a greater concentration of installed infrastructure. Low vulnerability (17.77\%), in general, was associated with areas devoid of occupations and infrastructure, normally located in the flood zones of the watercourse, while the average vulnerability was related to squares and open spaces, but endowed with some 362 infrastructure.

363 Favorable conditions for the development of geological accidents (classes with high and very high 364 AI) were observed in $38.76 \%$ of the investigated area, as can be seen in Figure 11. The Hazard cartogram indicated that cells with a higher level of hazard, concentrated in the concave section of the river, within the flood zones, since the level of high hazard was associated with the regions of 
widespread evidence of creeps and abatement measures. Moderate hazard, in turn, was associated

368 with compartments with high natural susceptibility (Figure 8), in which the signs of instability were

369 observed incipiently or are absent. Low hazard was associated with the risk model, with

370 compartments of low natural susceptibility, and without signs or evidence of instability.

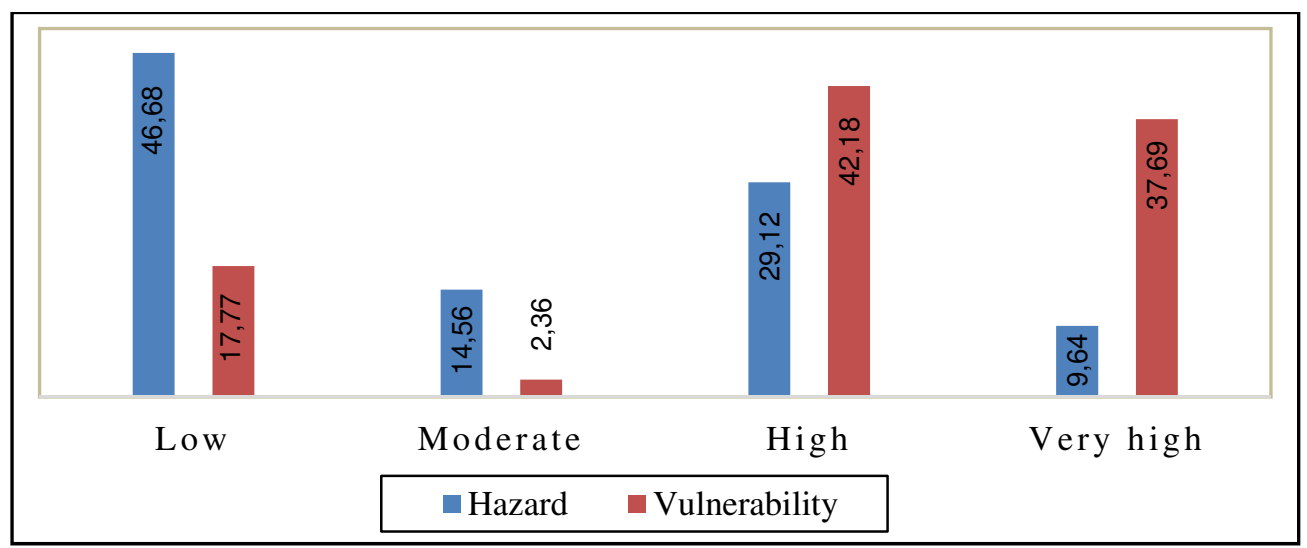

Figure 2 - Distribution of hazard and vulnerability classes, in percentage, for the study area.

371 The cartogram that expresses the risk (Figure 12) resulted from the cross-indexing of the RI (Figure 372 9) and HI (Figure 10) cartograms.

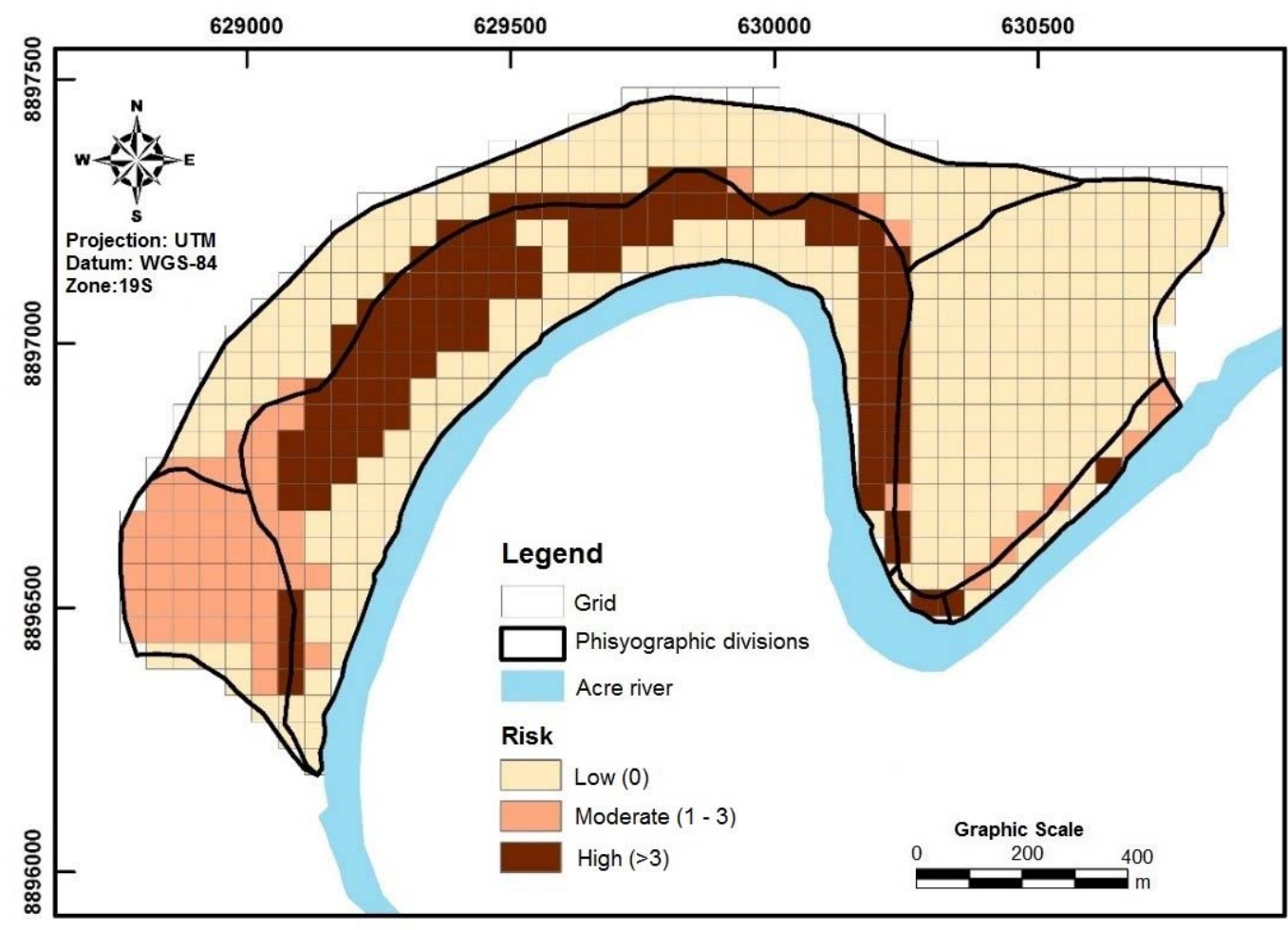

Figura 12- Mass movements risk chart. 
From the data presented in Table 8, it can be seen that the most critical situations (classes with moderate and high risk) were identified in $36 \%$ of the investigated area.

Table 8 - Distribution of risk classes.

\begin{tabular}{c|c|c|c}
\hline Degree of risk & Area $\left(\mathrm{m}^{2}\right)$ & № of cells & \% of area \\
\hline Low & 720150 & 304 & 64,01 \\
\hline Moderate & 154950 & 63 & 13,77 \\
\hline High & 250000 & 100 & 22,22 \\
\hline Total & 1.125 .100 & 467 & 100,00 \\
\hline
\end{tabular}

The decision on the type of action to be implemented, and the level of urgency for each action resulted from the cross-indexing the risk cartography and the hazard cartography, the results of which were summarized in Table 9 and represented in the cartogram in Figure 13.

Table 9 - Distribution of cells in accordance to mitigation actions.

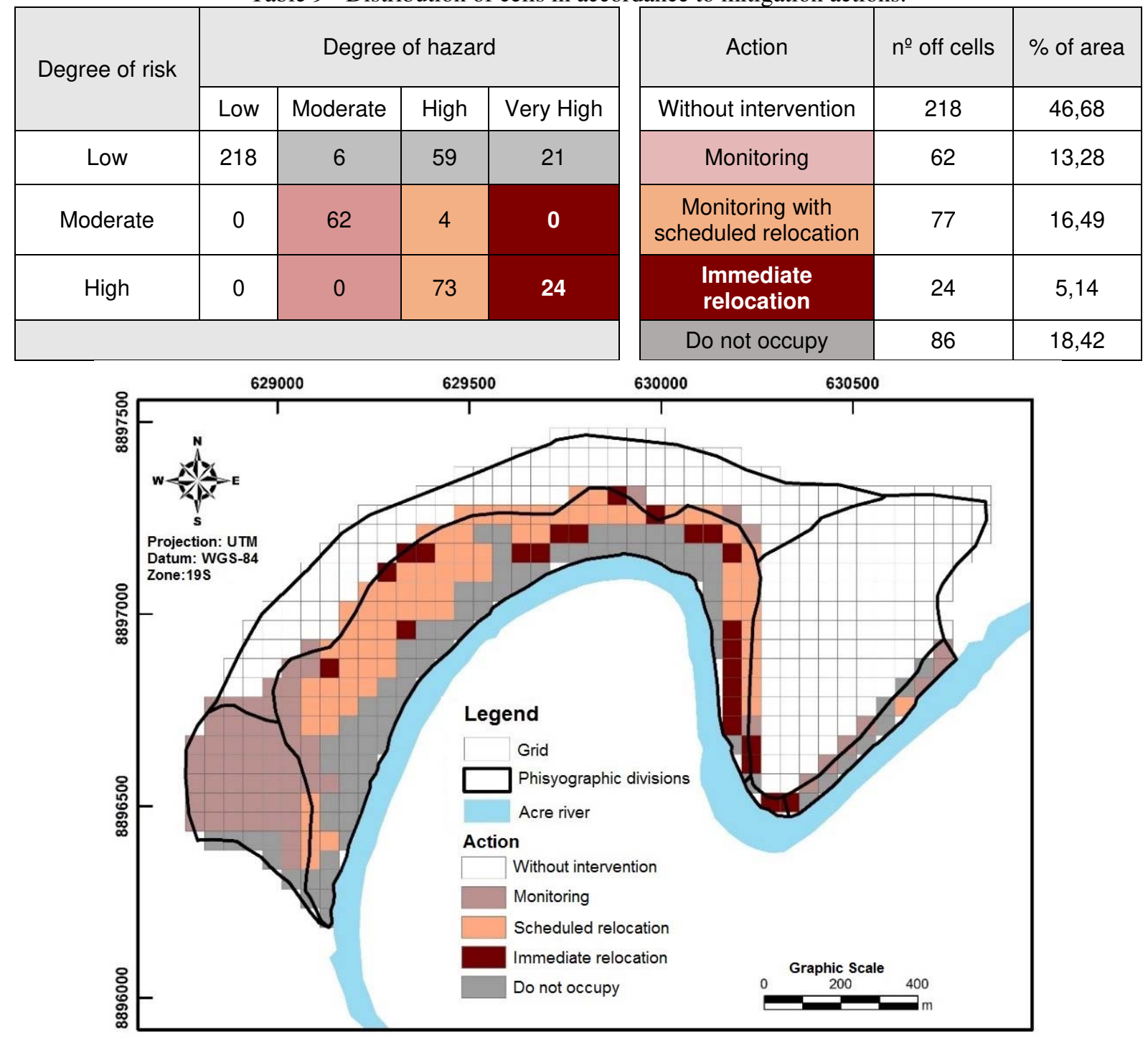

Figura 3 - Mitigation actions chart.

Figure 14 illustrates the overlapping of the information used to validate the risk model. 


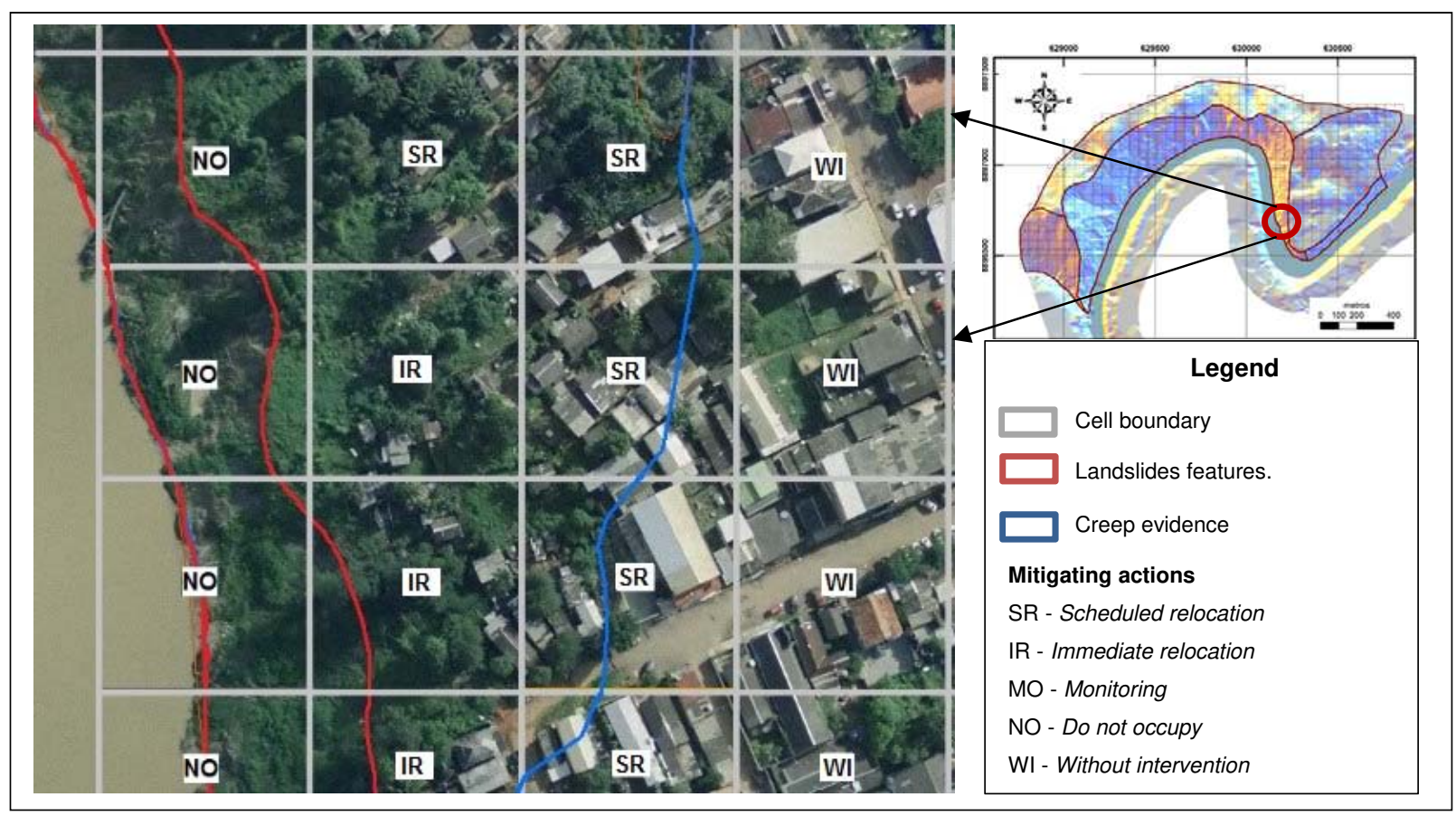

Figure 4 - Comparison between mitigation actions, instability (landslide) signs register and land use.

Based on the overlap of the registry of instability signs, the orthophoto mosaic and the actions indicated by the cartogram, we sought to subjectively assess the coherence between the action 384 indicated by the model, the registered processes and the properties observed in each cell.

385 The emergency actions related to the immediate relocation occurred in 5\% of the mapped area and correspond to the cells located in the vicinity of the largest channel bed, occupied by buildings with low construction standards, precarious infrastructure and, therefore, very vulnerable to the landslides frequently observed in this region.

As Figure 14 illustrates, the areas indicated for the programmed monitoring and / or relocation 390 follow the same pattern as the occupations observed in the critical areas, however, they are concentrated in lands with less declivity and whose predominant movement is creeping.

This work sought to provide aid in assisting in the management of the risk associated with gravitational mass movements, composed of creeping and rotational landslides, along watercourse margins and urban areas of a municipality in the Western Brazilian Amazon. It is noteworthy that these processes are of common occurrence throughout the western region of the Amazon. 
Due to the specificity of the theme, several criteria had to be developed or adapted in order for the analysis to consider certain environmental, economic and social particularities of the region.

The Hierarchical Analysis Method was the technique adopted to structure the decision-making process, so that the hierarchy of the problem and the prioritization of alternatives were based on the logical and quantified judgment that the method provides.

In terms of use and occupation, especially the construction pattern and the level of income of the population in the area studied, it was observed that the lower income population, characterized by subnormal settlements that occupy riverside areas, is in fact, the most exposed to the processes mapped. If, on the one hand, this population has developed ways to live with creeping (wooden constructions, with limited dimensions, located in an area free from infrastructure, among others), their physical and social condition makes them very vulnerable to landslides.

It was observed that the criteria and procedures described allowed the establishment of standards for the collection, organization, management and validation of the decision-making process, which contributes to the reduction of subjectivity in the identification of zones of different degrees of risk and in the implementation of short-term and medium term actions to reduce geological accidents.

The results suggest that the methodological proposal can be applied in other areas, for the study of the risk associated with other processes, which does not exempt it from the need for adequate knowledge about those processes, their relationship with the physical environment and the exposed elements.

\section{ACKNOWLEDGMENTS}

The authors would like to thank the Brazilian research agencies - CAPES and CNPq, for their support to the research. They also thank the municipal government of Rio Branco for the information provided and the professors of the Federal University of Acre for their assistance in the judgments made with the AHP method. 
1. CARVAlho, J. A. L. De; IGREJA, H. L. S. Da; CUNHA S. B. Da; CARneiro D. S. Episódio de terras caídas no rio amazonas: Caso Costa da Águia, Parintins-Am. In: XVIII Simpósio Brasileiro de Recursos Hídricos. Anais... Campo Grande, 2009.

2. CASCINI, L; BONNARD, CH.; COROMINAS, J; JIBSON, R. AND OLARTE-MONTERO, J. Landslide risk Management. Chapter: Landslide hazard and risk zoning for urban planning and development. Taylor \& Francis. London. 199-235, 2005.

3. CERRI, L.E.S.; NOGUEIRA, F. R.; CARVALHO, C. S.; MACEDO, E. S.; AUGUSTO FILHO, O. Mapeamento de Risco em assentamentos precários no município de São Paulo (SP). Geociências, n. 26, v. 2, p. 143- 150, 2007.

4. FARIA, D. G. M. \& AUGUSTO FILHO, O. Aplicação do Processo de Análise Hierárquica (AHP) no mapeamento de perigo de escorregamentos em áreas urbanas. Revista do Instituto Geológico, v. 34, n. 1, p. 23-44, 2013.

5. GOMES, M. F. M. Metodologia de análise hierárquica aplicada para escolha do sistema de disposição de subproduto da mineração com ênfase nos rejeitos de minério de ferro. 193p. Dissertação (Mestrado em Engenharia Geotécnica) - Universidade Federal de Ouro Preto, Ouro Preto, 2009.

6. INTARAWICHIAN, N. \& DASANANDA, S. Analytical hierarchy process for landslide susceptibility mapping in lower Mae Chaem watershed, northern Thailand. Suranaree J. Sci. Technol, v. 17, n. 3, p. 277-292, 2010.

7. JASIWAL, J. Landslide risk quantification along transportation corridors based on historical information. Masster Thesis. Univeristy of Tweete, The Netherlands. 243 p, 2011.

8. KAYASTHA, P.; DHITAL, M. R.; DE SMEDT, F. Application of the analytical hierarchy process (AHP) for landslide susceptibility mapping: A case study from the Tinau watershed, west Nepal. Computers \& Geosciences, v. 52, n. 0, p. 398 - 408, 2013.

9. LABADESSA, A. S. "Terras Caídas", as causas naturais e antrópicas: uma ocorrência na comunidade de São Carlos - Médio Madeira/RO. Geoingá, Maringá, v. 3, n. 1, p. 45-61, 2011.

10. MAGAlHÃES, R. C. \& GOMES, R. C. M. Mineralogia e química de solo de várzea e suas susceptibilidades no processo de terras caídas na comunidade do Divino Espírito Santo - AM. Sociedade \& Natureza, v. 25, n. 3, 2013.

11. MAIA, M. S. O. Zoneamento geotécnico do sítio urbano do município de Rio Branco/AC e seus arredores, para fins de planejamento com ênfase à expansão urbana, através do sensoriamento remoto. 116 f. Dissertação (mestrado). Instituto de Geociências e Ciências Exatas, Universidade Estadual Paulista, Rio Claro - SP, 2003.

12. MATOS, J. A. \& CURSINHO, A. M. S. Caracterização geomorfológica das "Terras-Caídas" em área de várzea na comunidade Miracauera, Careiro da Várzea - AM. Geonorte, Edição Especial, v. 1, n. 4, p. 515 - 525, 2012.

13. NASCIMENTO, R. R. Do. Procedimento baseado em rotina de apoio à decisão aplicado à redução de risco de movimentos gravitacionais de massa em margens de cursos d'água: estudo de caso em Rio Branco/AC, 2016. 
14. NASCIMENTO, R. R. Do. \& SIMÕES, G. F. Avaliação da suscetibilidade a movimentos de massa gravitacionais em margens de cursos d'água da cidade de Rio Branco (AC). Geociências, v. 36, n. 2, p. 233-249, 2017.

15. OLIVEIRA, A. M.; FERREIRA, A. L. Avaliação Geológico-Geotécnica da Cidade de Rio Branco; Relatório Final. CPRM - Companhia de Pesquisa de Recursos Minerais. Vol I. 57p. Manaus, 2006.

16. NOGUEIRA, F. R. Gestão dos Riscos nos Municípios. In: CARVALHO C. S.; GALVÃO T. (orgs.) Prevenção de Riscos de Deslizamentos em Encostas: Guia para Elaboração de Políticas Municipais. Brasília, Ministério das Cidades, Cities Alliance, 2006, p. 26-45.

17. NOLA, I.T.S.; ZUQUETTE, L. V. Procedures of engineering geological mapping applied to urban planning in a data-scarce area: Application in southern Brazil. Journal of South American Earth Sciences, v. 107, p. 103141, 2021. doi.org/10.1016/j.jsames.2020.103141

18. PACHECO, J. D. \& BRANDÃO, J. C. M. Geomorfologia fluvial do Rio Solimões/Amazonas: estratégias do povo vazeano do sudoeste do careiro da várzea. Geonorte, Edição Especial. Manaus. v.2, n.4. p.542 - 554, 2012.

19. PAULA, B. L. \& CERRI, L. E. S. Aplicação do Processo Analítico Hierarquico (AHP) para priorização de obras de intervenção em áreas e setores de risco geológico nos municípios de Itapecerica da Serra e Suzano (SP). Geociências, v. 31, n.2, p. 247-257, 2012.

20. RODRIGUES, B. B. \& ZUQUETTE, L. V. Elaboration of gravitational mass movement predisposition chart based on decision support method: part of the city of Ouro Preto, State of Minas Gerais, Brazil. IEAG: The Geological Society of London. Paper n. 178, 2006.

21. SAATY, T. L. A scaling method for priorities in hierarchical structures. Journal of mathematical psychology, v. 15, n. 3, p. 234-281, 1977.

22. SAATY, T. L. How to make a decision: the analytic hierarchy process. European journal of operational research, v. 48, n. 1, p. 9-26, 1990.

23. SAATY, T. L. Relative Measurement and its Generalization in Decision Making: Why Pairwise Comparisons are Central in Mathematics for the Measurement of Intangible Factors - The Analytic Hierarchy/Network Process. RACSAM-Revista de la Real Academia de Ciencias Exactas, Fisicas y Naturales. Serie A. Matematicas, v. 102, n. 2, p. 251-318, 2008.

24. SAATY, T. L. The Analytic Hierarchy Process. McGraw-Hill. New York, 1980.

25. SILVA, F. A. S. \& AZEVEDO, C. A. V. Principal Components Analysis in the Software Assistat-Statistical Attendance. In: WORLD CONGRESS ON COMPUTERS IN AGRICULTURE, 7, Reno-NV-USA: American Society of Agricultural and Biological Engineers, 2009. doi:10.13031/2013.29066

26. SOBREIRA, F. G. \& SOUZA, L. A. Cartografia geotécnica aplicada ao planejamento urbano. Revista Brasileira de Geologia de Engenharia e Ambiental, São Paulo, n. 2, p. 79-97. 2012.

27. UNISDR - UNITED NATIONS INTERNATIONAL STRATEGY FOR DISASTER REDUCTION. Como Construir Cidades Mais Resilientes - Um Guia para Gestores Públicos Locais, Genebra. p. 90, 2012. 
500 501 502
28. VEGA, J.A AND HIDALGO, C.A. (2016). Quantitative risk assessment of landslides triggered by earthquakes and rainfall based on direct costs of urban buildings. Geomorphology. 273:217-235. Doi: https://doi.org/10.1016/j.geomorph.2016.07.032 